\title{
OXYGEN CONSUMPTION DURING SPONTANEOUS VENTILATION WITH CONTINUOUS POSITIVE AIRWAY PRESSURE: ASSESSMENT IN NORMAL VOLUNTEERS AND PATIENTS WITH ACUTE RESPIRATORY FAILURE
}

\author{
Patrick Wherry, Firooz Sangoul, Gordon S. Fox and Lloyd D. Maclean
}

ABSTRACI

\begin{abstract}
Continuous positive airway pressures (CPAP) of $0.49 \mathrm{kPa}$ and $0.98 \mathrm{kPa}$ were applied to ten healthy volunteers and nine critically ill patients with acute respiratory failure. A modified Godart-Statham NV 16003 spirometer was used to measure respiratory frequency ( $f$ ), tidal volume (VT), oxygen consumption $\left(\dot{\mathrm{V}}_{2}\right)$, and changes in functional residual capacity ( $\triangle F R C$ ). During CPAP of $0.49 \mathrm{kPa}$, volunteers had a decrease in $f$, and increased $\mathrm{V} r$ and minute volume (MV). At $0.98 \mathrm{kPa}$ CPAP. f did not change but $\mathrm{VT}$ and $\mathrm{MV}$ significantly increased. $\mathrm{VO}_{2}$ did not change at either pressure. The volume of $\triangle F R C$ increased with an increased level of CPAP. The entire volunteer group was comfortable throughout the whole study.

When CPAP was applied to acutely ill patients, f decreased. VT and MV increased at both CPAP pressures. $\triangle F R C$ was similar to the volunteers. $\dot{V}_{O_{2}}$ in the patient group rose significantly at 0.49 and $0.98 \mathrm{kPa}$ CPAP. Some of the patients were uncomfortable with 0.49 $\mathrm{kPa}$ pressure, while all the patients were distressed at $0.98 \mathrm{kPa} C \mathrm{PAP}$.

The effects of increased oxygen consumption and patient discomfort should be considered in critically ill patients receiving CPAP therapy.
\end{abstract}

CONTINUOUS POSITIVE AIRWAY PRESSURE (CPAP) has been employed to improve pulmonary gas exchange in spontaneously breathing paticnts. CPAP has been utilized in the treatment of the idiopathic respiratory distress syndrome of infants, ${ }^{1}$ and has been applied to adults with acute respiratory failure. ${ }^{2,3}$ Adult respiratory distress syndrome is associated with a decrease in functional residual capacity (FRC). CPAP increases FRC to prevent or reverse closure of small airways and consequently improves oxygenation. In addition, the possible advantages of CPAP over mechanical ventilation with end-expiratory pressure include lower peak airway pressures and a lesser effect on cardiac output. ${ }^{2}$ We applied CPAP to groups of healthy volunteers and to patients with acute respiratory failure in order to compare the oxygen cost of breathing and tolerance in subjects with normal and severely compromised respiratory function. Respiratory frequency (f), tidal volume (VT), and oxygen consumption $\left(\dot{V}_{2}\right)$ were measured during CPAP. Oxygen consumption was used as a measure of the work of breathing. ${ }^{4}$

Patrick Wherry, M.D., F.R.C.S.(C); Firooz Sangoul, M.D.; Gordon S. Fox, M.D., F.R.C.P.(C); Lloyd D. MacLean. M.D. F.R.C.S.(C). Departments of Anaesthesia \& Surgery, Royal Victoria Hospital, \& McGill University, Montreal, Canada.

Supported by grants from Shell Canada Lid., and The Medical Research Council of Canada.

\section{METHODS}

\section{Subject selection}

Ten normal volunteers without pre-existing lung disease were studied. Their ages varied from 20 to 58 years. Nine critically ill patients with acute respiratory failure were also studied. In two of the patients the studies, were repeated on separate occasions. Their age span was 23 to 80 years. Details of the patient's history, surgical procedures and postoperative complications are presented (Table I).

\section{Materials and technique}

A Godart-Statham NV 16003 spirometer with a carbon dioxide absorber in the circuit was used to measure respiratory frequency, tidal volume, oxygen consumption and changes in functional residual capacity.

CPAP was applied by placing weights, manometrically equivalent to $0.49 \mathrm{kPa}\left(5 \mathrm{~cm} \mathrm{H} \mathrm{H}_{2} \mathrm{O}\right)$ and $0.98 \mathrm{kPa}\left(10 \mathrm{~cm} \mathrm{H}_{2} \mathrm{O}\right)$ on the spirometer bell. The spirometer was modified by increasing the length of the water container to prevent overflow. Silicone bars were used inside the water container to maintain the bell in a vertical position (Figure 1). This modification did not interfere with the free movement of the spirometer bell.

All volunteers were studied in the supine position. A mouthpiece and nose clips, reinforced with adhesive tape, were used to prevent gas 
TABLE I

Patient Data

\begin{tabular}{|c|c|c|c|c|}
\hline $\begin{array}{l}\text { Patient } \\
\text { No. }\end{array}$ & Sex & $\begin{array}{l}\text { Age } \\
\text { (yrs) }\end{array}$ & History & CPAP \\
\hline 1 & $\mathbf{M}$ & 52 & $\begin{array}{l}\text { Ruptured aortic aneurysm, resection, } \\
\text { severe G.I. hemorrhage }\end{array}$ & 1 \\
\hline 2 & $\mathbf{F}$ & 75 & MVA, multiple injuries & 2 \\
\hline 3 & $\mathbf{M}$ & 23 & MVA, quadraplegia, septicemia & 1 \\
\hline 4 & M & 74 & $\begin{array}{l}\text { MVA, multiple trauma, gas } \\
\text { gangrene, leg amputation }\end{array}$ & 2 \\
\hline 5 & M & 72 & Craniotomy & 1 \\
\hline 6 & $\mathbf{F}$ & 80 & Bowel resection & 1 \\
\hline 7 & M & 63 & $\begin{array}{l}\text { Laparotomy, perforated gall bladder, } \\
\text { peritonitis }\end{array}$ & 1 \\
\hline 8 & M & 57 & $\begin{array}{l}\text { MVA, ruptured diaphragm, } \\
\text { splenectomy, bowel resection, } \\
\text { fractured ribs, tracheostomy }\end{array}$ & 1 \\
\hline 9 & M & 20 & $\begin{array}{l}\text { MVA, fractured maxilla, mandible, } \\
\text { ribs, pelvis, femur, ruptured } \\
\text { diaphragm }\end{array}$ & 1 \\
\hline
\end{tabular}

MVA $=$ motor vehicle accident

$\mathrm{CPAP}=$ number of times observations made during CPAP.

leakage. The patients were also studied in the supine position. They had either a tracheal tube or a tracheostomy tube in place and the cuffs on these tubes were inflated during the study period to prevent airway leakage.

After allowing adjustment to the apparatus for seven minutes while breathing room air. the circuit was closed at end of expiration and respirations were recorded for seven minutes each at 0 , 0.49 and $0.98 \mathrm{kPa}$ of water pressure. During this period the subjects breathed 100 per cent oxygen. Between each pressure setting the subject breathed room air for a seven-minute period at zero end-expiratory pressure.

Respiratory parameters were calculated from the spirograph tracing. $\dot{V}_{2}$ was determined from the slope of the spirometer recording. The vertical distance from the initial base line to the one established at the end of seven minutes was measured as the litres of oxygen consumed (Figure 2).

Correction for the compression of the oxygen in the total circuit (beneath the spirometer bell and in the spirometer circuit) due to the applied weight was made by calculating the actual

volume of oxygen in the total circuit

$\dot{\mathrm{V}}_{2}=\frac{\text { before CPAP } \times \mathrm{VO}_{2} \text { measured }}{\text { volume of oxygen in the total }}$ circuit after CPAP.

Mean $f$ and mean $V t$ were measured from the tracings. Mean minute volumes (MV) were calculated as their product. Changes in FRC ( $\triangle F R C$ ) were calculated from the change of the base line after several respiratory cycles with CPAP. No corrective factor was applied to the measured values of $\triangle F R C$. 5 The compliance of the total respiratory system $\left(C_{r s}\right)$ was determined by dividing $\triangle F R C$ by the applied pressure for CPAP.

All measurements for each group were performed within the same room. VT, MV, and $\triangle F R C$ were changed to BTPS and $V o_{2}$ was corrected to STPD. The Wilcoxon matched-pairs signed-rank test was used for statistical analysis.

\section{RESULTS}

The values measured and calculated from the spirometer tracings are presented for the normal volunteers (Table II) and the patients with acute respiratory failure (Table III).

With a CPAP pressure of $0.49 \mathrm{kPa}$, the volunteers demonstrated a significant decrease in $f$, an increase in VT and MV. When the airway pressure was raised from 0 to $0.98 \mathrm{kPa}, \mathrm{f}$ did not change but $V T$ and $M V$ significantly increased. $\mathrm{V}_{2}$ did not change at the 0.49 and 0.98 CPAP levels. The volume of $\triangle F R C$ increased significantly for each level of applied airway pressure. $\mathrm{C}_{\mathrm{r}}$ remained unchanged throughout CPAP. 


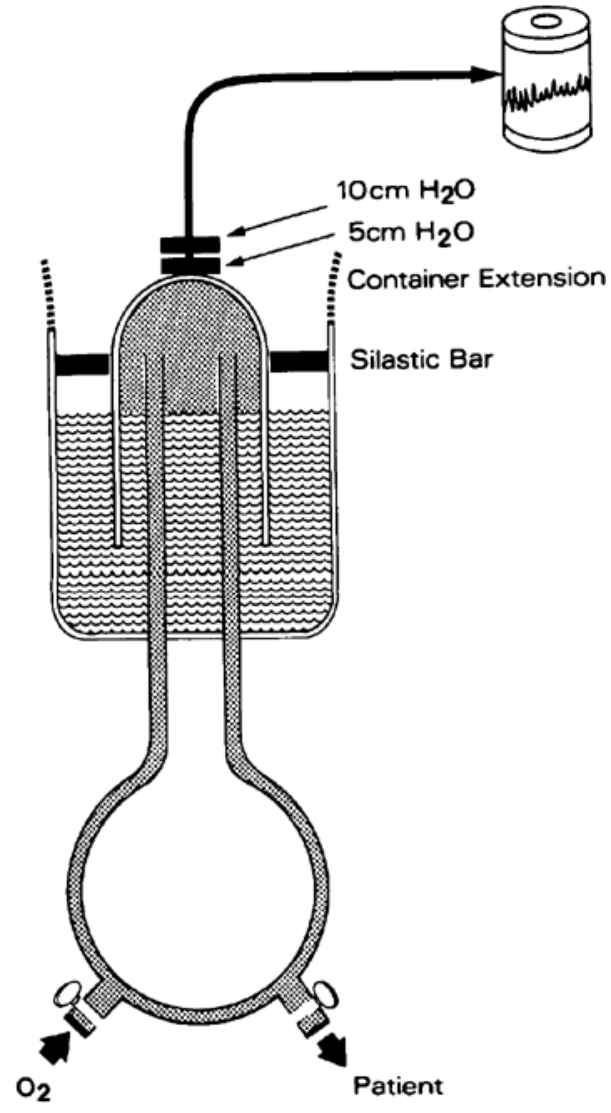

Figure 1 Diagrammatic respresentation of the tota circuit for applying CPAP with the modified spirograph. Total circuit equals the volume of oxygen beneath the bell in the apparatus tubes.

Respiratory frequency decreased in the patient group at both levels of CPAP. Tidal volume rose significantly at both levels of CPAP and this was reflected in a significant increase in $\mathrm{MV}$ at 0.49 and $0.98 \mathrm{kPa} \mathrm{CPAP}$. $\mathrm{VO}_{2}$ increased significantly on changing from zero end-expiratory pressure to 0.49 and $0.98 \mathrm{kPa}$ CPAP. FRC results followed the same pattern as that observed in the normal volunteers and increased with changes to positive pressure breathing.

Further comparison between the two groups shows that respiratory frequency both initially and throughout the study period was twice as fast in the patient group compared to healthy individuals. Tidal volume in the patients with acute respiratory failure was smaller than in normal subjects prior to and during CPAP. A portion of this difference is due to the presence of tracheal

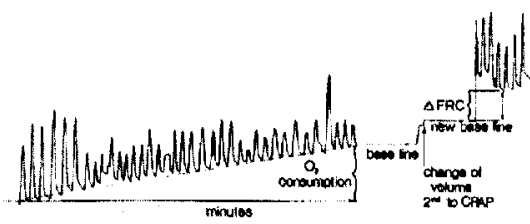

Figure $2 \dot{V}_{2}(1 / \mathrm{min})$ is calculated by dividing total oxygen consumption by the time. New base line occurs after the application of CPAP. $\triangle F R C$ is measured from the new base line to end expiration.

or tracheostomy tubes in the patients. This decreased their dead space and consequently their tidal volume. The volunteer group tolerated CPAP without discomfort, to the point where subjects five and six slept. Some of the ill subjects became uncomfortable at $0.49 \mathrm{kPa}$ CPAP while all patients were obviously distressed at the 0.98 $\mathrm{kPa}$ level.

\section{Discussion}

The work of breathing consists of three components: elastic work, flow resistance, and inertional work. ${ }^{6.7}$ Mead $^{8}$ and Dubois ${ }^{9}$ found the latter to be negligibly small and recoverable at the end of a respiratory cycle. By negleeting this inertial component, Otis determined that the mechanical work of inspiration could be approximated by the formula

Winsp $=\frac{1}{2 \mathrm{C}_{\mathrm{rs}}} \mathrm{V}^{2} \mathrm{~T}+\frac{K_{1}}{4} \pi^{2} \mathrm{f} \mathrm{V}^{2} \mathrm{~T}+\frac{2 K_{2}}{3} \pi^{2} \mathrm{f}^{2} \mathrm{~V}^{3} \mathrm{~T}$

where $K_{1}$ and $K_{2}$ are constants related to the flow-resistive properties of the respiratory system. Expiratory work can also be ignored as it is usually passive except at very high values of ventilation. ${ }^{10}$

While not synonymous, the work of breathing has been estimated as the oxygen cost of respiration. ${ }^{10}$ During quiet ventilation the work of breathing represents only a fraction of the total oxygen consumption, and as such is difficult to measure." Increasing $f$, particularly above 30 breaths/minute, disproportionately increases this value. ${ }^{10}$ In contrast, the supine position enhances the efficiency of ventilation. ${ }^{12}$

The spirometer circuit and techniques of measurement may influence the recorded values. During the application of CPAP with 100 per cent oxygen equilibration of nitrogen occurs throughout the circuit. However, this should be approximately of the same magnitude and in the 
TABLE II

Respiratory Data During CPAP: Volunterers

\begin{tabular}{|c|c|c|c|c|c|c|c|}
\hline $\begin{array}{l}\text { Volun- } \\
\text { teer } \\
\text { No. }\end{array}$ & $\begin{array}{l}\text { Airway } \\
\text { pressure } \\
\text { kPa }\end{array}$ & $\begin{array}{c}\mathrm{f} \\
\text { (breaths/ } \\
\text { minute) }\end{array}$ & $\begin{array}{c}\mathrm{VT} \\
(\mathrm{ml} \text { BTPS})\end{array}$ & $\begin{array}{c}\text { MV } \\
\text { (1 BTPS) }\end{array}$ & $\begin{array}{c}\dot{\mathrm{Vo}_{2}} \\
\text { (ml/minute) } \\
\text { STPD }\end{array}$ & $\begin{array}{c}\triangle \text { FRC } \\
(\text { I BTPS) }\end{array}$ & $\begin{array}{c}\mathrm{C}_{r s} \\
(1 / \mathrm{kPa})\end{array}$ \\
\hline 1 & $\begin{array}{l}0 \\
0.49 \\
0.98\end{array}$ & $\begin{array}{l}20 \\
18 \\
16\end{array}$ & $\begin{array}{l}573 \\
672 \\
760\end{array}$ & $\begin{array}{l}11.56 \\
12.1 \\
12.2\end{array}$ & $\begin{array}{l}289 \\
330 \\
339\end{array}$ & $\begin{array}{l}0.661 \\
1.21\end{array}$ & $\begin{array}{l}-\overline{3} \\
1.2\end{array}$ \\
\hline 2 & $\begin{array}{l}0 \\
0.49 \\
0.98\end{array}$ & $\begin{array}{l}10 \\
13 \\
16\end{array}$ & $\begin{array}{r}992 \\
1378 \\
1686\end{array}$ & $\begin{array}{r}9.9 \\
17.9 \\
26.9\end{array}$ & $\begin{array}{l}339 \\
395 \\
411\end{array}$ & $\begin{array}{l}0.551 \\
1.102\end{array}$ & $\begin{array}{l}-\overline{1.12} \\
1.12\end{array}$ \\
\hline 3 & $\begin{array}{l}0 \\
0.49 \\
0.98\end{array}$ & $\begin{array}{l}16 \\
12 \\
11\end{array}$ & $\begin{array}{r}694 \\
981 \\
1135\end{array}$ & $\begin{array}{l}11.1 \\
11.8 \\
12.5\end{array}$ & $\begin{array}{l}353 \\
298 \\
338\end{array}$ & $\begin{array}{l}0.386 \\
0.529\end{array}$ & $\begin{array}{l}-\overline{0.79} \\
0.54\end{array}$ \\
\hline 4 & $\begin{array}{l}0 \\
0.49 \\
0.98\end{array}$ & $\begin{array}{l}8 \\
6 \\
6\end{array}$ & $\begin{array}{r}716 \\
1069 \\
1124\end{array}$ & $\begin{array}{l}5.7 \\
6.4 \\
6.7\end{array}$ & $\begin{array}{l}173 \\
212 \\
173\end{array}$ & $\begin{array}{l}0.331 \\
0.441\end{array}$ & $\begin{array}{l}-\overline{0.68} \\
0.45\end{array}$ \\
\hline 5 & $\begin{array}{l}0 \\
0.49 \\
0.98\end{array}$ & $\begin{array}{l}11 \\
11 \\
10\end{array}$ & $\begin{array}{l}838 \\
882 \\
992\end{array}$ & $\begin{array}{l}9.2 \\
9.7 \\
9.9\end{array}$ & $\begin{array}{l}266 \\
258 \\
249\end{array}$ & $\begin{array}{l}0.661 \\
1.21\end{array}$ & $\begin{array}{l}\overline{1.3} \\
1.2\end{array}$ \\
\hline 6 & $\begin{array}{l}0 \\
0.49 \\
0.98\end{array}$ & $\begin{array}{l}13 \\
12 \\
11\end{array}$ & $\begin{array}{l}463 \\
496 \\
573\end{array}$ & $\begin{array}{l}6.0 \\
6.0 \\
6.3\end{array}$ & $\begin{array}{l}232 \\
215 \\
232\end{array}$ & $\begin{array}{l}0.386 \\
0.606\end{array}$ & $\begin{array}{l}-\overline{0.79} \\
0.62\end{array}$ \\
\hline 7 & $\begin{array}{l}0 \\
0.49 \\
0.98\end{array}$ & $\begin{array}{l}15 \\
13 \\
11\end{array}$ & $\begin{array}{r}661 \\
827 \\
1080\end{array}$ & $\begin{array}{r}9.9 \\
10.7 \\
11.9\end{array}$ & $\begin{array}{l}372 \\
380 \\
388\end{array}$ & $\begin{array}{l}0.441 \\
0.716\end{array}$ & $\begin{array}{l}\overline{0.90} \\
0.73\end{array}$ \\
\hline 8 & $\begin{array}{l}0 \\
0.49 \\
0.98\end{array}$ & $\begin{array}{r}14 \\
10 \\
8\end{array}$ & $\begin{array}{l}353 \\
529 \\
639\end{array}$ & $\begin{array}{l}4.9 \\
5.3 \\
5.1\end{array}$ & $\begin{array}{l}248 \\
250 \\
273\end{array}$ & $\begin{array}{l}0.419 \\
0.551\end{array}$ & $\begin{array}{l}-\overline{0.86} \\
0.56\end{array}$ \\
\hline 9 & $\begin{array}{l}0 \\
0.49 \\
0.98\end{array}$ & $\begin{array}{l}21 \\
16 \\
14\end{array}$ & $\begin{array}{l}551 \\
716 \\
827\end{array}$ & $\begin{array}{l}11.6 \\
11.5 \\
11.6\end{array}$ & $\begin{array}{l}274 \\
265 \\
242\end{array}$ & $\begin{array}{l}0.551 \\
0.771\end{array}$ & $\begin{array}{l}-\overline{1.12} \\
0.79\end{array}$ \\
\hline 10 & $\begin{array}{l}0 \\
0.49 \\
0.98\end{array}$ & $\begin{array}{l}18 \\
15 \\
12\end{array}$ & $\begin{array}{l}463 \\
551 \\
716\end{array}$ & $\begin{array}{l}8.3 \\
8.3 \\
8.6\end{array}$ & $\begin{array}{l}430 \\
397 \\
372\end{array}$ & $\begin{array}{l}-1 \overline{0.441} \\
0.827\end{array}$ & $\begin{array}{l}-\overline{0.90} \\
0.84\end{array}$ \\
\hline $\begin{array}{l}\text { Mean } \\
\quad \pm S D\end{array}$ & $\begin{array}{l}0 \\
0.49 \\
0.98\end{array}$ & $\begin{array}{l}14.6(4.3) \\
12.6(3.3) \\
11.5(3.2)\end{array}$ & $\begin{array}{l}631(191) \\
810(279) \\
953(328)\end{array}$ & $\begin{array}{r}8.8(2.5) \\
10.0(3.8) \\
11.2(6.1)\end{array}$ & $\begin{array}{l}298(76) \\
301(71) \\
302(79)\end{array}$ & $\begin{array}{l}-\overline{(1.2)} \\
0.48(1.29)\end{array}$ & $\begin{array}{l}\overline{0} \\
0.98(0.22) \\
0.81(0.28)\end{array}$ \\
\hline & $\begin{array}{l}0-0.49 \\
0-0.98\end{array}$ & $\stackrel{*}{N S}$ & $*$ & * & $\begin{array}{l}\text { NS } \\
\text { NS }\end{array}$ & $*$ & NS \\
\hline
\end{tabular}

$f=$ respiratory frequency.

$V T=$ tidal volume.

$\mathrm{MV}=$ minute volume.

$\dot{\mathrm{V}}_{2}=$ oxygen consumption.

$\triangle F R C=$ change in functional residual capacity.

$C_{r s}=$ total respiratory compliance.

$\mathrm{SD}=$ standard deviation .

* $=\mathrm{p}<0.05$.

NS $=$ not significant.

same direction at each level of CPAP in individual subjects and, therefore, should not invalidate recorded observations. Increased alveolar pressure after the application of CPAP caused the measured $\triangle F R C$ to be larger than the actual $\triangle F R C$. However, this error is very small at 0.49 and 0.98 $\mathrm{kPa}$ and therefore no corrective calculations were done. The change in FRC on the application of CPAP in our volunteer group is almost identical to that noted by Abboud. ${ }^{13}$ In his study FRC increased 0.4 litres and 0.8 litres after $0.49 \mathrm{kPa}$ and $0.98 \mathrm{kPa}$ respectively.

Within the volunteer population, application of 0.49 and $0.98 \mathrm{kPa}$ caused $f$ and $V T$ to change in 
TABLE $11 \mathrm{I}$

Respiratory Data During CPAP: Patients

\begin{tabular}{|c|c|c|c|c|c|c|c|}
\hline $\begin{array}{c}\text { Patient } \\
\text { No. }\end{array}$ & $\begin{array}{l}\text { Airway } \\
\text { pressure } \\
\text { kPa }\end{array}$ & $\begin{array}{c}\mathrm{f} \\
\text { (breaths/ } \\
\text { minute) }\end{array}$ & $\begin{array}{l}\mathrm{V}_{\mathrm{r}} \\
(\mathrm{ml} \mathrm{BT} \mathrm{PS})\end{array}$ & $\begin{array}{c}\text { MV } \\
\text { (l BTPS) }\end{array}$ & $\begin{array}{c}\dot{\mathrm{V}}_{\mathrm{O}_{2}} \\
\text { (ml/minute) } \\
\text { STPD }\end{array}$ & $\begin{array}{c}\text { FRC } \\
\text { (I BTPS) }\end{array}$ & $\begin{array}{c}\mathrm{C}_{\text {rs }} \\
(\mathrm{l} / \mathrm{kPa})\end{array}$ \\
\hline 1 & $\begin{array}{l}0 \\
0.49 \\
0.98\end{array}$ & $\begin{array}{l}25 \\
28 \\
28\end{array}$ & $\begin{array}{l}331 \\
419 \\
452\end{array}$ & $\begin{array}{r}8.3 \\
11.7 \\
12.7\end{array}$ & $\begin{array}{l}306 \\
363 \\
379\end{array}$ & $\begin{array}{l}0.330 \\
0.551\end{array}$ & $\begin{array}{l}-\overline{0.67} \\
0.56\end{array}$ \\
\hline $2-A$ & $\begin{array}{l}0 \\
0.49 \\
0.98\end{array}$ & $\begin{array}{l}44 \\
40 \\
38\end{array}$ & $\begin{array}{l}220 \\
264 \\
287\end{array}$ & $\begin{array}{r}9.7 \\
10.6 \\
10.9\end{array}$ & $\begin{array}{l}228 \\
259 \\
314\end{array}$ & $\begin{array}{l}0 . \overline{0.441} \\
0.661\end{array}$ & $\begin{array}{l}\overline{0.90} \\
0.67\end{array}$ \\
\hline $2-B$ & $\begin{array}{l}0 \\
0.49 \\
0.98\end{array}$ & $\begin{array}{l}24 \\
20 \\
20\end{array}$ & $\begin{array}{l}441 \\
496 \\
496\end{array}$ & $\begin{array}{r}10.6 \\
9.9 \\
9.9\end{array}$ & $\begin{array}{l}232 \\
248 \\
248\end{array}$ & $\begin{array}{l}0.331 \\
0.551\end{array}$ & $\begin{array}{l}-\overline{0.68} \\
0.56\end{array}$ \\
\hline 3 & $\begin{array}{l}0 \\
0.49 \\
0.98\end{array}$ & $\begin{array}{l}28 \\
26 \\
25\end{array}$ & $\begin{array}{l}551 \\
617 \\
749\end{array}$ & $\begin{array}{l}15.4 \\
16.0 \\
18.7\end{array}$ & $\begin{array}{l}494 \\
594 \\
594\end{array}$ & $\begin{array}{l}0.441 \\
0.771\end{array}$ & $\begin{array}{l}-\overline{0.90} \\
0.79\end{array}$ \\
\hline $4-A$ & $\begin{array}{l}0 \\
0.49 \\
0.98\end{array}$ & $\begin{array}{l}31 \\
29 \\
28\end{array}$ & $\begin{array}{l}276 \\
309 \\
353\end{array}$ & $\begin{array}{l}8.5 \\
8.9 \\
9.9\end{array}$ & $\begin{array}{l}218 \\
226 \\
242\end{array}$ & $\begin{array}{l}0.441 \\
0.771\end{array}$ & $\begin{array}{l}-\overline{0.90} \\
0.79\end{array}$ \\
\hline 4-B & $\begin{array}{l}0 \\
0.49 \\
0.98\end{array}$ & $\begin{array}{l}20 \\
18 \\
15\end{array}$ & $\begin{array}{l}386 \\
441 \\
551\end{array}$ & $\begin{array}{l}7.7 \\
7.9 \\
8.3\end{array}$ & $\begin{array}{l}223 \\
240 \\
265\end{array}$ & $\begin{array}{l}-\overline{0.331} \\
0.551\end{array}$ & $\begin{array}{l}-\overline{0.68} \\
0.56\end{array}$ \\
\hline 5 & $\begin{array}{l}0 \\
0.49 \\
0.98\end{array}$ & $\begin{array}{l}18 \\
18 \\
16\end{array}$ & $\begin{array}{l}386 \\
551 \\
716\end{array}$ & $\begin{array}{r}6.9 \\
9.9 \\
11.5\end{array}$ & $\begin{array}{l}190 \\
289 \\
331\end{array}$ & $\begin{array}{l}0 . \overline{220} \\
0.441\end{array}$ & $\begin{array}{l}- \\
0.45 \\
0.45\end{array}$ \\
\hline 6 & $\begin{array}{l}0 \\
0.49 \\
0.98\end{array}$ & $\begin{array}{l}38 \\
25 \\
25\end{array}$ & $\begin{array}{l}220 \\
386 \\
441\end{array}$ & $\begin{array}{r}8.4 \\
9.6 \\
11.0\end{array}$ & $\begin{array}{l}207 \\
248 \\
273\end{array}$ & $\begin{array}{l}0.22 \\
0.551\end{array}$ & $\begin{array}{l}-\overline{0.45} \\
0.56\end{array}$ \\
\hline 7 & $\begin{array}{l}0 \\
0.49 \\
0.98\end{array}$ & $\begin{array}{l}40 \\
30 \\
25\end{array}$ & $\begin{array}{l}231 \\
386 \\
496\end{array}$ & $\begin{array}{r}9.3 \\
11.6 \\
12.4\end{array}$ & $\begin{array}{l}223 \\
248 \\
273\end{array}$ & $\begin{array}{l}0.331 \\
0.771\end{array}$ & $\begin{array}{l}0.90 \\
0.79\end{array}$ \\
\hline 8 & $\begin{array}{l}0 \\
0.49 \\
0.98\end{array}$ & $\begin{array}{l}20 \\
20 \\
15\end{array}$ & $\begin{array}{l}386 \\
551 \\
661\end{array}$ & $\begin{array}{r}7.7 \\
11.0 \\
9.9\end{array}$ & $\begin{array}{l}331 \\
397 \\
455\end{array}$ & $\begin{array}{l}0.33 \\
0.33 \\
0.55\end{array}$ & $\begin{array}{l}0.67 \\
0.67 \\
0.56\end{array}$ \\
\hline 9 & $\begin{array}{l}0 \\
0.49 \\
0.98\end{array}$ & $\begin{array}{l}21 \\
20 \\
20\end{array}$ & $\begin{array}{l}441 \\
496 \\
551\end{array}$ & $\begin{array}{r}9.3 \\
9.9 \\
11.0\end{array}$ & $\begin{array}{l}314 \\
347 \\
372\end{array}$ & $\begin{array}{l}0.22 \\
0.44\end{array}$ & $\begin{array}{l}-\overline{0.45} \\
0.45\end{array}$ \\
\hline $\begin{array}{l}\text { Mean } \\
\quad \pm S D\end{array}$ & $\begin{array}{l}0 \\
0.49 \\
0.98\end{array}$ & $\begin{array}{l}28.1(9.0) \\
24.9(6.7) \\
23.2(6.9)\end{array}$ & $\begin{array}{l}351(107) \\
447(107) \\
523(144)\end{array}$ & $\begin{array}{r}9.3(2.3) \\
10.6(2.1) \\
11.5(2.7)\end{array}$ & $\begin{array}{l}270(88) \\
314(109) \\
341(106)\end{array}$ & $\begin{array}{l}-\overrightarrow{0.9} \\
0.34(0.9) \\
0.60(0.12)\end{array}$ & $\begin{array}{l}-\overline{0.70}(0.19) \\
0.61(0.13)\end{array}$ \\
\hline & $\begin{array}{l}0-0.49 \\
0-0.98\end{array}$ & * & * & * & $*$ & * & $\begin{array}{l}\text { NS } \\
\text { NS }\end{array}$ \\
\hline
\end{tabular}

$\mathrm{f}=$ respiratory frequency.

$V_{T}=$ tidal volume.

$\mathrm{MV}=$ minute volume.

$\dot{\mathrm{V}}_{2}=$ oxygen consumption.

$\Delta \mathrm{FRC}=$ change in functional residual capacity.

$C_{r s}=$ total respiratory compliance.

$\mathrm{SD}=$ standard deviation.

* $=\mathrm{p}<0.05$.

$\mathrm{NS}=$ not significant.

opposite directions. The increase in $\mathrm{VT}$ was sufficiently large to increase MV. Expiratory work can be ignored as $f$ was low. However, flow-resistive work might decrease secondary to increased laryngeal diameter ${ }^{14}$ increased airway conductance 15.16 and decreased flow-resistance of the chest wall ${ }^{17}$ associated with the increased lung volumes. The net result is no appreciable 
change in $\mathrm{VO}_{2}$ and the work of breathing at a CPAP level of $0.98 \mathrm{kPa}$ in normal volunteers. This was substantiated by subjective statements of the volunteers and obvious comfort during CPAP.

In acutely ill patients, 0.49 and $0.98 \mathrm{kPa}$ CPAP produced similar results. Respiratory frequency decreased, $V T$ and $M V$ increased at both levels of CPAP. If the values for $f, V T$, and $C_{r s}$ are substituted in the formula for respiratory work, an increase in work would be expected. Measurement of $\dot{\mathrm{V}}_{2}$ supports this theory. Clinically, patient distress became obvious at $0.98 \mathrm{kPa}$ CPAP.

Previous investigation by Barach ${ }^{18.19}$ disclosed an increase in $\dot{\mathrm{V}}_{2}$ with CPAP. The present study refined these observations and demonstrated that this may become measurable in a patient with respiratory impairment at $0.49 \mathrm{kPa} \mathrm{CPAP}$ and distress the adult patient at $0.98 \mathrm{kPa}$ CPAP. This might explain the excellent clinical results obtained in the studies of Civetta ${ }^{2}$ and Glasser ${ }^{3}$ who utilized levels of $0.49 \mathrm{kPa}$ in two of the three patients they reported.

Increased $\dot{\mathrm{V}}_{2}$ during CPAP may be limited to adults with acute respiratory failure. Following open-heart surgery, Askitopoulou ${ }^{20}$ showed no difference in $\dot{V}_{2}$ during CPAP and spontaneous respiration in eleven patients. However, these patients had relatively normal pulmonary function following surgery.

Shah"1 noted differences in $\mathrm{VO}_{2}$ in adult patients with respiratory distress syndrome during CPAP and intermittent positive pressure ventilation with and without positive end expiratory pressure (PEEP). On changing from PEEP ventilation to CPAP with the same end expiratory pressure, he found no differences in mean $\dot{\mathrm{V}}_{2}$ between the two modes of breathing. However. seven of eleven measurements of $\mathrm{VO}_{2}$ showed an increase on changing from $P E E P$ to CPAP. In two of his patients he measured $\mathrm{VO}_{2}$ at 0.49 and 0.98 $\mathrm{kPa} C P A P$ and in both situations $\dot{\mathrm{V}}_{2}$ was greater with $0.98 \mathrm{kPaCPAP}$. Therefore, in any individual patient selected for CPAP, the benefits of this mode of therapy should be weighed against the possible deleterious effects of increased oxygen consumption and objective patient distress.

\section{SUMMARY}

Continuous positive airway pressure (CPAP) was utilized in spontaneously breathing adult volunteers and in adult patients with acute respiratory failure. Respiratory frequency (f), tidal volume (VT), change in functional residual capacity $(\triangle \mathrm{FRC})$ and oxygen consumption $\left(\dot{\mathrm{V}}_{2}\right)$ were measured. Minute volume (MV) and total lung compliance $\left(\mathrm{C}_{\mathrm{rs}}\right)$ were calculated. These values were determined for CPAP pressures of 0.49 and $0.98 \mathrm{kPa}$. Oxygen consumption in patients increased with increasing levels of CPAP, but remained unchanged in the healthy volunteers. The increase in $\mathrm{VO}_{2}$ coincided with the appearance of clinical discomfort and distress in the patient population. These observations suggest that in addition to measurements of cardiorespiratory performance, levels of CPAP administered to spontaneously breathing patients with acure respiratory failure might be titrated against patient discomfort.

\section{REFERENCES}

1. Gregory, G.A., Kitterman, J.A.. Phibbes, R.H. , ToOleY, W.H. \& Hamilton, W.K. Treatment of IRDS with continuous positive airway pressure. N. Engl. J. Med. 284: 1333-1340 (1971).

2. Civetta. J.M., Brons. R. \& Gabel. J.C. A simple and effective method of employing spontaneous positive pressure ventilation. I. Thorac. Cardiovasc. Surg. 63: 313-317 (1972).

3. Glasser. K.L., CivetTa, J.M. \& Flor, R.J. The use of spontaneous ventilation with constant positive airway pressure in the treatment of salt water near drowning. Chest 67: 355-357 (1975).

4. White, A.. Hadler, P.\& Smith, E.L. Principles of Biochemistry, Fifth Edition. McGraw-Hill Book Co., New York, pp. 282-283 (1973).

5. RAhN. H., Otis, A.B., Chadwick. L.E. \& FENN, W.O. The pressure-volume diagram of the thorax and lung. Am. J. Physiol 146: 161-178(1946).

6. OtIs, A.B. Handbook of Physiology, Section 3, Respiration, Volume 1. Section Editors: Fenn, W.O., Rahn, H. American Physiological Society, Washington, D.C., pp. 463-476 (1964).

7. Agostoni, E. A graphic analysis of thoracoabdominal mechanics during breathing cycle. J. Appl. Physiol. 16: 1055-1059 (1961).

8. MEAD, J. Measurement of inertia of the lungs at increased ambient pressure. J. Appl. Physiol. 9; 208-212 (1956).

9. Dubois, A.B.. Brody, A.W.. Lewis, D.H. \& Burges, B.F., JR. Oscillation mechanics of lungs and chest in men. J. Appl. Physiol. 8: 587-594 (1956).

10. Campbell. E.J.M., Agostoni, E. \& Davis, J.M. The respiratory muscles: mechanics and neural control. Second cdition, W.B. Saunders Co.. Philadelphia and London, pp. 115-137 (1970).

11. KaretSkY, M.S. \& CAIN, S.M. Effect of carbon dioxide on oxygen uptake during hyperventilation in normal man. J. Appl. Physiol. 28: 8-12 (1970).

12. Milic-Emili, J. \& Petit, J.M. Mechanical efficiency of breathing. J. Appl. Physiol. 15: 359-362 (1960).

13. Abboud, N., Rehder, K., Rodarte, J.R. \& HYATT, R.E. Lung volumes and closing capacity with continuous positive airway pressure. Anesthesiology 42: 138-142(1975). 
14. Ferris, B.G.. Mead, J. \& Opit, L.H. Partitioning of respiratory flow resistance in man. J. Appl. Physiol. 19:653-658 (1964).

15. BriscolE, W.A. \& DuBois, A.B. The relationship between airway resistance, airway conductance and lung volume in subjects of different age and body size. J. Clin. Invest. 37: 1279-1285 (1958).

16. Fisher, A.B. Dubois. A.B. \& HydE. R.W. Evaluation of the forced oscillation technique for the determination of resistance to breathing. J. Clin. Invest. 47: 2045-2057 (1968).

17. Grimbly. G., Takishima, T., Graham, W. MaCKLEM, P. \& MEAD. J. Frequency dependence of flow resistance in patients with obstructive lung disease. J. Clin. Invest. 47: 1455-1465 (1968).

18. Barach. A.L. Martin, J. \& Eckman, M. Positive pressure respiration and its application to the treatment of acute pulmonary edema. Ann. Intern. Med. 12: 754-795 (1938).
19. Barach, A.L., Eckman, M. Ginsburg, E.. Rumsey, C.C., Jr.. Korr. I.. Eckman. I. \& Dessun, G. Studies on positive pressure respiration: I: General aspects and types of pressure breathing. II: Effects on respiration and circulation at sea level. J. A viation Medicine 17: 290-320 (1946).

20. Askitopoulou, H., Sykes. M.K. \& Young. C. Cardiorespiratory effects of increased airway pres. sure during controlled and spontaneous breathing after cardiac surgery. Br. J. Anaesth. 50: 1203-1208 (1978).

21. Shah, D.M.. Newell, J.C., Dutton. R.E. \& POWERS, S.R., JR. Continuous positive airway pressure versus positive end-expiratory pressure in respiratory distress syndrome. J. Thorac. Cardiovasc. Surg. 74: 557-562(1977).

RÉSUMÉ

On soumis dix vuluntaires en respiration spontanée à des pressions positives continues (CPAP) de 0.49 et de $0.98 \mathrm{kPa}$ (5 et $10 \mathrm{~cm} \mathrm{H}_{2} \mathrm{O}$ ), ainsi que neuf grands malades en insuffisance respiratoire aiguë. Un spirometre modifié de Godart-Statham NV 16003 a été utilisé pour la mesure de la fréquence respiratuire, du volume courant, de la consommation d' oxygène et des modifications de la capacité fonctionnelle résiduelle.

Une diminution de la fréquence respiratoire avec une augmentation du volume courant et du volume-minute a été observée chez les volontaires soumis à une CPAP de $0.49 \mathrm{kPa}$. Si on soumettait ces sujets à une $\mathrm{CPAP}$ de $0.98 \mathrm{kPa}$. la fréquence respirat cire demeurait inchangée alors que le volume courant et le volume-minute s'élevaient de façon significative. La consummation d'oxygène ne changeait pas avec l'une ou l'autre des pressions utilisées chez les volontaircs. La capacité fonctionnelle résiduelle augmentait en relation avec l'importance de la CPAP appliquée. Ces sujets sont demeurés confortables durant toute l'épreuve.

La fréquence respiratoire diminuait avec augmentation du volume courant et du volumeminute chez les patients en insuffisance respiratoire aiguë, et ceci aux deux régimes de pression positive. On observait les mêmes modifications de la capacité résiduelle fonctionnelle déjà mentionnées chez les volontaires. Par ailleurs. la consommation d'oxygène $s$ 'élevait avec l'utilisation des deux régimes de pression. Avec une CPAP de $0.49 \mathrm{kPa}$ quelques uns des malades étaient inconfortables, alors que tous l'étaient de façon évidente à $0.98 \mathrm{kPa}$.

On devrait tenir compte du fait que la consommation d'oxygène est augmentée, ainsi que de l'inconfort des patients lorsque l'on utilise une CPAP chez les grands malades en insuffisance respiratoire aiguë. 